\title{
Editorial: A Promising Future for Advancement
}

The economy is in the doldrums. The threat of international terrorism is a daily reality. Higher education budgets are being slashed. Endowments are under water. Giving is in decline. Advancement shops are in retrenchment. In this environment, anxiety is palpable and it is not unreasonable for advancement professionals to be concerned about the future of their profession, their institutions, and their careers. But, in the midst of such pressures and concerns, it may be useful to hold a longer perspective, gained by looking back on the early years of the three preceding decadesthe 1970s, 1980s, and 1990s.

I began my career in higher education in 1971. My first day on the job an older colleague delivered to my desk a copy of the higher education best seller of the time, entitled The New Depression in Higher

Education, accompanied by his advice that as a young man I perhaps should consider pursuing "a different line of work." This Carnegie Commission report, written by Earl F. Cheit, predicted the imminent demise of many colleges, especially those similar to the one at which I was then employed! ${ }^{1}$ Some writers of that period pointed to the current economic recession as well as demographic trends that also were highly unfavorable to higher education and predicted a gloomy future for all colleges and universities. More than thirty years later, most institutions that existed then have indeed survived, even thrived.

A decade later, in 1981, an advancement best seller was entitled Institutional
Advancement Strategies in Hard Times, by Michael D. Richards and Gerald R. Sherratt. ${ }^{2}$ At about that time, I attended a conference at which a corporate CEO explained why the American economy was truly doomed. He said that the Japanese were more efficient and the Soviet Union would steal our technology, leaving the United States to fall farther and farther behind into permanent economic stagnation. Needless to say, the European economy was virtually given up for dead, viewed as hopelessly ensnarled in government regulation and socialism. More than twenty years later, the Japanese economy is in ruins, the Soviet Union is no more, the American economy stands as the world's strongest, and a unifying European economy has become a significant force. In advancement, the 1980s offered new records of support and the first billion-dollar campaigns.

At the beginning of the next decade, during 1991 and 1992, I edited a book entitled Educational Fund Raising: Principles and Practice, which was published by the American Council on Education in $1993 .{ }^{3}$ Some of the authors in that volume pointed to the poor economic climate of the times and predicted that the era of biggoal campaigns was over and that institutions would forevermore need to be "realistic" in setting their fund-raising sights. In the following years, the US economy soared to new heights and campaigns set new records, including the largest gifts to educational institutions ever. 
So, here we are in 2003. And hard times are with us once again. Two college presidents, Michael McPherson of Macalester and Morton Owen Schapiro of Williams, cochairs of the Ford Policy Forum, have written a report, with the somewhat reminiscent title "The New Depression in Higher Education,"4 pointing to the challenges that current economic conditions present to higher education in the United States. In the April 2003 issue of Currents, Donna Shoemaker documents the impact of hard times on colleges and universities and advancement programs, citing the quadruple whammy of "funding cutbacks, which result in tuition hikes, which create greater demand for institution-based financial aid from the largest population of college students ever."5

I do not intend to ignore or diminish the real human pain associated with dramatic increases in tuition or with reductions in institutional staff and budgets. Nor should we underestimate the negative long-term impact on colleges and universities of even temporary stringencies that create a loss of continuity and momentum in their advancement programs. I do not intend to "blow off" these difficulties and their considerable costs. But history strongly suggests that doomsayers are always wrong, that hard times eventually are followed by new levels of economic prosperity, and that higher education institutions continue to endure. Despite the difficult environment it faces today, advancement is likely to offer promising careers long into the future.

Indeed, despite today's pressures, one can imagine that advancement will emerge from this period as an even more important component of higher education management. As David Breneman observes in the Chronicle of Higher Education, reductions in state funding for public institutions and endowment declines in private institutions are leading both to increase tuition significantly, raising concerns about educational opportunity for students who do not have financial resources and heightening the attention paid to quality and value by those who can afford to pay. ${ }^{6}$ These trends can only intensify the competitive environment and increase the need for fund raising as well as enhanced communications, marketing, and constituent relations programs. The effectiveness of these efforts and the skills of professionals who can manage them will only become more essential to the continued vitality of colleges and universities in the decades ahead. Moreover, the efforts of advancement professionals will be instrumental not just in strengthening institutions, but also in preserving our national commitment to educational opportunity and other central values of higher education.

There has been no year in history yet in which better times were not ahead. Hard times always have been followed by recovery and further growth. The worst predictions have always been wrong. Advancement programs have continued to expand in their scale, scope, and importance on college and university campuses for the past fifty years, interrupted only temporarily by periodic recessions. It seems difficult to believe that the current year is the first in history in which the future offers only a downward spiral. And it seems unlikely that colleges and universities that face a more competitive environment will respond by reducing more than temporarily the intensity of their efforts to secure understanding and support. Those who 
find doomsayers persuasive may wish to consider pursuing "a different line of work." Those who find history instructive may prefer to spend the current difficult time in strengthening their programs and honing their professional skills in anticipation of new opportunities and rewards in the decades ahead.

\section{References}

1. E. F. Cheit (1973), The New Depression in Higher Education: A Study of Financial Conditions at 41 Colleges and Universities, McGraw-Hill: New York.

2. M. D. Richards and G. R. Sherratt (1981), Institutional Advancement Strategies in Hard Times, The George Washington University (ERIC Clearinghouse on Higher Education), Washington, DC.

3. M. J. Worth (Ed.) (1993), Educational Fund Raising: Principles and Practice. Oryx Press/American Council on Education, Phoenix, AZ.
4. M. McPherson and M. O. Schapiro (2003), "The new depression in higher education," in Futures Forum 2002, Forum for the Future of Higher Education, Cambridge, MA and EDUCASE, Boulder, CO. Viewed online May 20, 2003 <http:// www.educause.edu/ir/library/pdf/ffp0207s.pdf $>$.

5. D. Shoemaker (2003), "Crunching numbers," Currents, 29, 4, p. 18.

6. D. Breneman (2002), "For colleges, this is not just another recession," Chronicle of Higher Education, June 14, p. B7.

\author{
Michael J. Worth \\ Professor of Nonprofit Management, \\ The George Washington University, \\ Washington, $D C$
}

